\title{
Phase Equilibria in the Subsystem Barium Disilicate-- Dibarium Trisilicate
}

\author{
Robert S. Roth and Ernest M. Levin
}

\begin{abstract}
A revised phase equilibrium diagram for the subsystem $\mathrm{BaO} \cdot 2 \mathrm{SiO}_{2}-2 \mathrm{BaO} \cdot 3 \mathrm{SiO}_{2}$ is presented. The previously published diagram showing a complete solid solution series was not verified. Instead, two new compounds were identified by X-ray diffraction powder pattern techniques, and two eutectics were located by the quenching method. The compound $3 \mathrm{BaO} .5 \mathrm{SiO}_{2}$ melts incongruently at $1,423^{\circ} \mathrm{C}$ to form $5 \mathrm{BaO} \cdot 8 \mathrm{SiO}_{2}$ and liquid. The latter compound melts congruently at $1,446^{\circ} \mathrm{C}$. Barium disilicate was found to have a quenchable and slowly reversible phase transformation at about $1,350^{\circ} \mathrm{C}$. The $\mathrm{X}$-ray diffraction powder pattern for $2 \mathrm{BaO} \cdot 3 \mathrm{SiO}_{2}$ was indexed for the first time on the basis of a monoclinic unit cell.
\end{abstract}

\section{Introduction}

In a study of the phase equilibria of the binary system $\mathrm{BaO}-\mathrm{SiO}_{2}$, P. Eskola [1] ${ }^{1}$ confirmed the existence of barium disilicate, previously reported by Bowen [2]. The phase diagram published by Eskola showed complete solid solution between $\mathrm{BaO} \cdot 2 \mathrm{SiO}_{2}$ and $2 \mathrm{BaO} \cdot 3 \mathrm{SiO}_{2}$. Rogers [3] discovered the existence of barium disilicate in nature and gave it the mineral name of sanbornite. In order to reconcile his findings with those of Bowen and Eskola, Rogers postulated dimorphism in $\mathrm{BaSi}_{2} \mathrm{O}_{5}$, indicating that sanbornite was probably triclinic, whereas the synthetic material was apparently orthorhombic. In a study of the $\mathrm{BaO}-\mathrm{Al}_{2} \mathrm{O}_{3}-\mathrm{SiO}_{2}$ system, R. H. Thomas [4] concluded that dibarium trisilicate probably was not a compound, but rather a fortuitous end-member of a solid solution series.

Levin and Ugrinic [5] and Toropov, Galakhov, and Bondar [6] concluded that dibarium trisilicate most likely was a true compound and that complete solid solution existed between it and barium disilicate. Levin and Ugrinic, nevertheless, state, "The X-ray data, however, did not conclusively show a solid solution series. The powder pattern for the composition containing 70.8 percent $\mathrm{BaO} \cdot 2 \mathrm{SiO}_{2}(29.2$ percent of $2 \mathrm{BaO} \cdot 3 \mathrm{SiO}_{2}$ ) showed several double peaks which indicated the presence of two phases. Even after an additional melting and grinding of the mixture, these double peaks persisted."

R. M. Douglass [7] recently reported the crystal structure of the mineral sanbornite. The unit cell was found to be orthorhombic with $a=4.63 \mathrm{~A}$, $b=8.69 \mathrm{~A}$, and $c=13.53 \mathrm{~A}$. Douglass concluded that barium disilicate did not show polymorphism although his X-ray diffraction powder pattern did not match that of Levin and Ugrinic [5].

On the basis of the structure determined for sanbornite, Douglass [7] doubted that extensive solid

1 Figures in brackets indicate the literature references at the end of this paper. solution existed between barium disilicate and dibarium trisilicate.

The opinions expressed by Douglass led to a reexamination of the possibilities of polymorphism in barium disilicate. Unpublished high-temperature X-ray patterns prepared during the original investigation of Levin and Ugrinic [5] had not been interpreted as showing conclusive evidence of polymorphism. However, with the ability to index the low-temperature form, as a result of Douglass' work, polymorphic transformation was clearly indicated in these patterns. In a note preliminary to this publication [8] polymorphism in barium disilicate was announced. The complete data supporting that statement are presented in this paper. In an attempt, also, to resolve the controversial question of solid solution in barium disilicate, a detailed reexamination is reported for the subsystem $\mathrm{BaO}$. $2 \mathrm{SiO}_{2}-2 \mathrm{BaO} \cdot 3 \mathrm{SiO}_{2}$.

\section{Apparatus and Method}

Phase equilibrium relationships in the system were studied by the well-established quenching technique. It was found that all liquids could be readily quenched to glasses. Constant temperature control of the quench furnace to within $\pm 3^{\circ} \mathrm{C}$ was achieved with a self-adjusting, a-c bridge-type controller [9]. Quenched samples were examined with the polarizing microscope and by X-ray powder diffraction patterns (Ni-filtered CuK radiation) using a high-angle Geiger-counter diffractometer.

Temperatures were measured with a platinum versus platinum-rhodium $(10 \%)$ thermocouple which was taken from lengths of thermocouple wire which had been originally calibrated by the Pyrometry Laboratory. Temperatures are given on the International Temperature Scale of 1948. During the course of the experiments the thermocouple was checked three times against the melting point of barium disilicate $\left(1,420^{\circ} \mathrm{C}\right)$. 


\section{Preparation of Mixtures}

Starting materials for the preparation of mixtures consisted of reagent grade (ACS) barium carbonate and silica gel of 99.99-percent purity on an ignited weight basis. The silica gel was specially prepared by an acid digestion process in the Chemistry Division.

The end-members $\mathrm{BaO} \cdot 2 \mathrm{SiO}_{2}$ and $2 \mathrm{BaO} \cdot 3 \mathrm{SiO}_{2}$ as well as the composition containing 37.4-mole percent $\mathrm{BaO}$ were specimens used in a previous study [5], and their preparation was described therein. Six intervening mixtures with $\mathrm{BaO}$ contents ranging from 34- to 39-mole percent, in 1-mole-percent increments, were prepared as follows: Calculated amounts, for 3-g mixtures, of barium carbonate and silica gel were thoroughly blended for $1 / 2 \mathrm{hr}$ with a high-speed mechanical mixer. The mixtures were then ground for $1 / 2$ to $3 / 4 \mathrm{hr}$ in an agate mechanical grinder. Specimens, $5 / 8$ in. in diameter, were formed by pressing the material in a mold at approximately $20,000 \mathrm{psi}$. The pressed disks were fired in a pot furnace at about $1,300^{\circ} \mathrm{C}$ for $24 \mathrm{hr}$. The disks were ground through a No. 200 sieve, pressed as before, and given a second heat treatment at $1,375^{\circ} \pm 15^{\circ} \mathrm{C}$ for $84 \mathrm{hr}$. Finally, the disks were ground to pass a No. 200 sieve. The two relatively long-time, hightemperature, heat treatments of pressed specimens were sufficient, apparently, to give homogeneous samples, as determined by inspection with the polarizing microscope.

For locating compounds and eutectics, 5 additional l-g samples were prepared from the appropriate amounts of previously prepared adjacent samples. The method of combination was similar to that for the $3-\mathrm{g}$ samples.

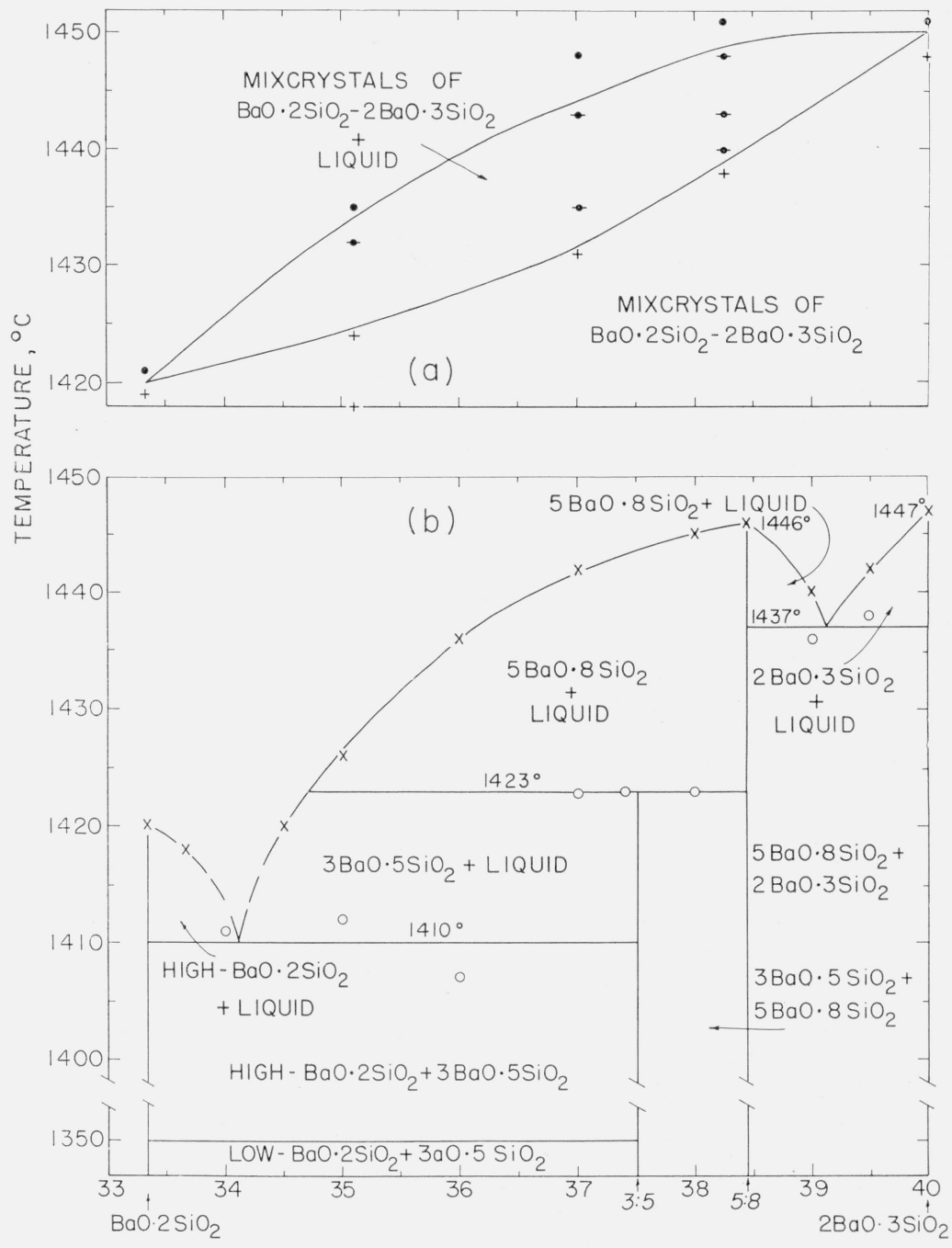

$\mathrm{BaO}, \mathrm{MOL} \%$

FIgure 1. Phase equitibrium diagrams proposed for the subsystem $\mathrm{BaO} \cdot 2 \mathrm{SiO}_{2}-2 \mathrm{BaO} \cdot 3 \mathrm{SiO}_{2}$.

(a) Continuous solid solution diagram according to Eskola [1], with data converted to mole percent. mixerystals and glass; + , mixerystals.

(b) Diagram without solid solution, according to the present work, showing two compounds and two eutectics. $X$, liquidus value; $O$, solidus value. 


\section{Results and Discussion}

The results of the experiments in the system $\mathrm{BaO} \cdot 2 \mathrm{SiO}_{2}-2 \mathrm{BaO} \cdot 3 \mathrm{SiO}_{2}$ are listed in table 1 for the 14 different compositions studied. These results have been interpreted to give the phase diagram shown in figure 1. Identification of crystalline phases by the polarizing microscope is given in the table only for those cases in which X-ray identification was not possible, because of a large proportion of glass. Because of overlapping indices of refraction, accurate identification of the crystalline phases present was difficult or impossible for many of the specimens. However, maximum and minimum indices usually were determined, and they were found to be compatible with the X-ray data.

\subsection{Polymorphism of Barium Disilicate}

Results of the experiments listed in table 1 for the 2 specimens containing 33.33-mole-percent $\mathrm{BaO}$ prove the existence of polymorphism in $\mathrm{BaSi}_{2} \mathrm{O}_{5}$. The heat treatment used to prepare the first composition listed in table 1 yielded the low-temperature form of $\mathrm{BaO} \cdot 2 \mathrm{SiO}_{2}$, or sanbornite. It may be seen that the low-temperature form remains stable at temperatures below $1,340^{\circ} \mathrm{C}$. At temperatures of $1,352^{\circ} \mathrm{C}$ and above, however, the high-temperature form appears, in amounts which increase with the time and temperature of heat treatment. For example, the sample heated at $1,360^{\circ} \mathrm{C}$ for $1.5 \mathrm{hr}$ failed to produce any detectable amounts of the hightemperature form, whereas the sample heated at $1,358^{\circ} \mathrm{C}$ for $16 \mathrm{hr}$ showed appreciable conversion.

High-temperature X-ray diffraction patterns of the original low-temperature form were available from a previous study [5]. Upon re-examination the following features were observed: Except for slight shifts in interplanar spacings due to thermal expansion, no change was observed up to $1,300^{\circ} \mathrm{C}$. After several hours at $1,375^{\circ} \mathrm{C}$. notable differences were apparent in the diffraction pattern. The X-ray pattern of the sample, furnace-cooled to room temperature, still showed the high form of barium disilicate.

The second composition listed in table 1 was not initially heat treated below $1,390^{\circ} \mathrm{C}$. It showed the pure high-temperature form. When it was heated at $1,335^{\circ} \mathrm{C}$ for $18 \mathrm{hr}$, the low-temperature form appeared in abundance. Interpretation of these data leads to the conclusion that barium disilicate exhibits a slowly reversible polymorphic transformation at $1,350^{\circ} \mathrm{C} \pm 10^{\circ} \mathrm{C}$.

Figure 2 shows schematically the X-ray diffraction powder patterns of the 2 polymorphs compared with the patterns reported by Austin [10] and Douglass [7] for $\mathrm{BaO} \cdot 2 \mathrm{SiO}_{2}$. It is obvious from this figure that sanbornite (Douglass [7]) is identical with the low-temperature form of $\mathrm{BaO} \cdot 2 \mathrm{SiO}_{2}$, found in the present work. Austin's data appear to represent, at least in part, a poorly resolved pattern for high $\mathrm{BaO} \cdot 2 \mathrm{SiO}_{2}$.

The X-ray diffraction powder pattern for hightemperature $\mathrm{BaO} \cdot 2 \mathrm{SiO}_{2}$ obtained in the present study is compared in table 2 with the pattern published by Levin and Ugrinic [5]. The present pattern is probably more accurate as it seems likely that the $\mathrm{X}$-ray diffraction equipment used for the earlier work was out of alinement. The final accuracy of the $d$ values must await indexing of the pattern following a determination of the unit-cell parameters.

The X-ray diffraction powder patterns of the 2 polymorphs are superficially simiar in that many of the strong lines of both patterns almost coincide. However, when an attempt is made to index the pattern of the high-temperature form, it is found that many of the interplanar spacings cannot be assigned indices on the basis of a structure resembling sanbornite. The diffraction peak at $2 \theta=25.1^{\circ}$ or $d=$ $3.54 \mathrm{~A}$, is diagnostic of the high-temperature form. A number of other peaks cannot be reconciled with the sanbornite structure, as, for example, those at approximately $16^{\circ}$ and $19^{\circ}$ and the triplet at $28.5^{\circ}$ $2 \theta$ (see fig. 2). It may be concluded that Douglass'

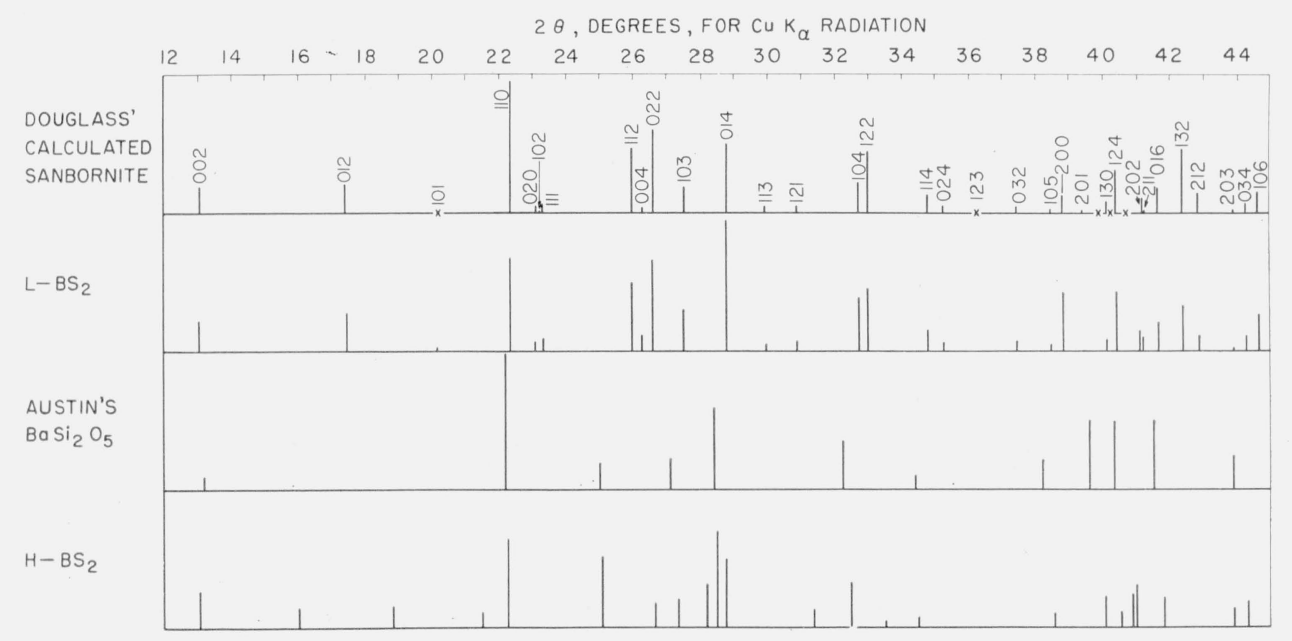

FIgure 2. Schematic X-ray diffraction powder patterns for the polymorphs of $\mathrm{BaO}^{\circ} 2 \mathrm{SiO}_{2}$ compared with two previously published patterns [\%, 10]. 
pattern is different from those reported by any of the authors mentioned in his paper [7]. Although Douglass correlated his pattern with Austin's published data, the present work proves that this correlation is incorrect. Austin's data should actually be correlated with the high-temperature form, as was done originally by Levin and Ugrinic [5].

\subsection{Compound $2 \mathrm{BaO} \cdot 3 \mathrm{SiO}_{2}$}

In order to obtain sufficient data to index the powder pattern, single crystals of $2 \mathrm{BaO} .3 \mathrm{SiO}_{2}$ were grown by A. Perloff of the Bureau on a hot-wire apparatus [11]. Precession patterns established the symmetry of the crystal as monoclinic, probably space group $C_{2}^{2}-P 2_{1}$ or $C_{2 h}^{2}-P 2_{1 / m}$. Using the approximate cell dimensions provided by Perloff, the X-ray diffraction powder pattern was indexed (table 3). The unit-cell parameters calculated from the powder pattern are: $a=12.51 \mathrm{~A} ; b=4.69 \mathrm{~A}$; $c=6.97 \mathrm{~A}$; and $\beta=93^{\circ} 23^{\prime}$.
Specimens of the composition containing 40-molepercent $\mathrm{BaO}$ heated at $1,400^{\circ} \mathrm{C}$ for $3 \mathrm{hr}$ or at $1,442^{\circ}$ $\mathrm{C}$ for $0.5 \mathrm{hr}$ (table 1) showed the same phase, namely, that present in the original starting material and in the crystals grown from the melt. The $d$ values for this phase did not change regardless of composition or time and temperature of treatment. Consequently, within the limits of the present experiments, dibarium tricilicate shows neither polymorphism nor solid solution. The liquidus temperature of $2 \mathrm{BaO} \cdot 3 \mathrm{SiO}_{2}$ was determined to be $1,447^{\circ}$ $\mathrm{C}$, or about $3^{\circ}$ less than that reported by Eskola.

\subsection{Phase Diagram for the System $\mathrm{BaO} \cdot 2 \mathrm{SiO}_{2}-$ $2 \mathrm{BaO} \cdot 3 \mathrm{SiO}_{2}$}

The phase diagram as reported by Eskola [1] (Fig. 1a) shows a continuous solid solution between $\mathrm{BaO} \cdot 2 \mathrm{SiO}_{2}$ and $2 \mathrm{BaO} \cdot 3 \mathrm{SiO}_{2}$, without maximum or minimum. It should be noted that this diagram is based on only 3 intermediate compositions.

TABLE 1. Compositions studied and phases identified in the system $\mathrm{BaO} \cdot 2 \mathrm{SiO}_{2}-2 \mathrm{BaO} \cdot 3 \mathrm{SiO}$

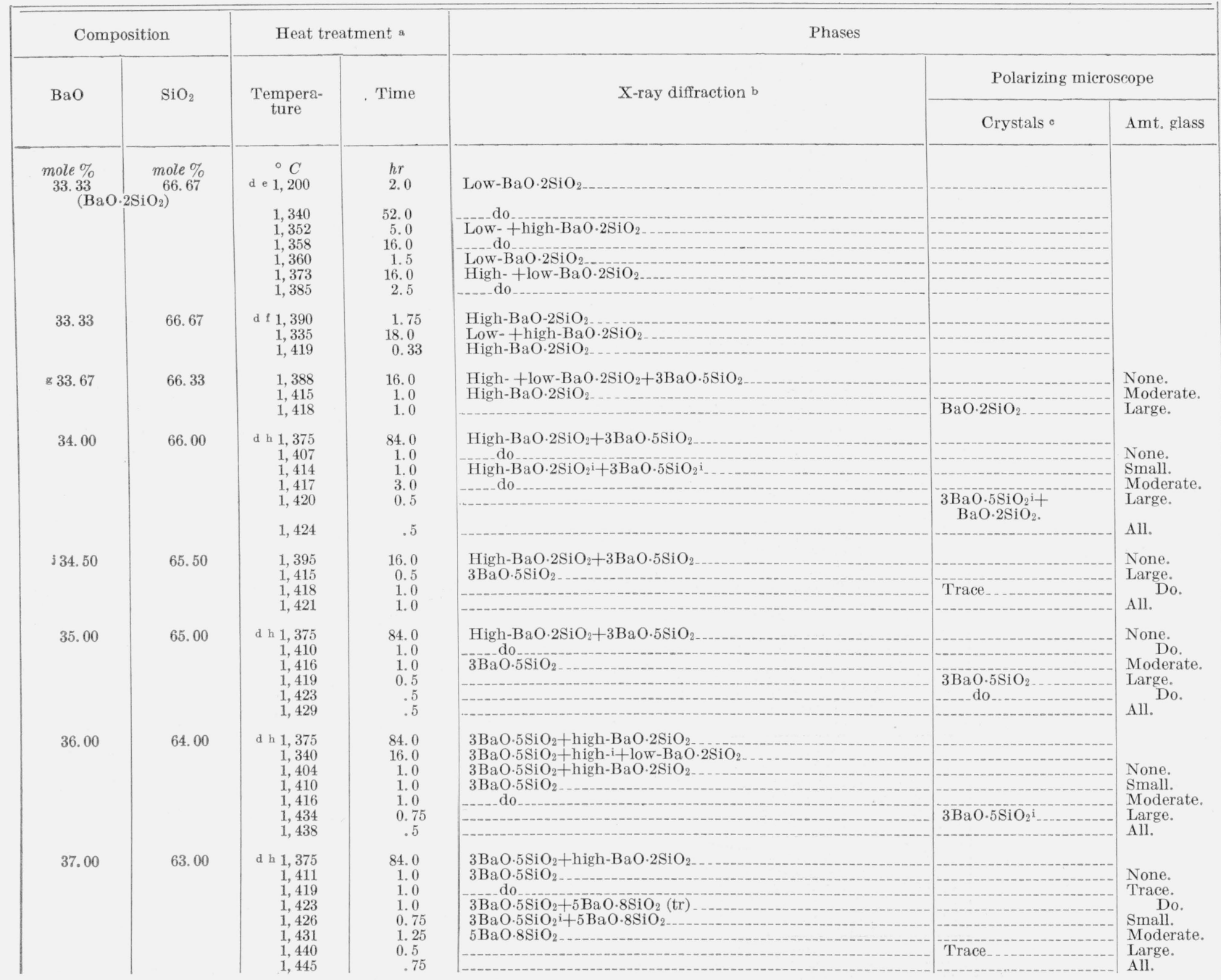

See footnotes at end of table. 
TABLE 1. Compositions studied and phases identified in the system $\mathrm{BaO} \cdot 2 \mathrm{SiO}_{2}-2 \mathrm{BaO} \cdot 3 \mathrm{SiO}_{2}-\mathrm{Continued}$

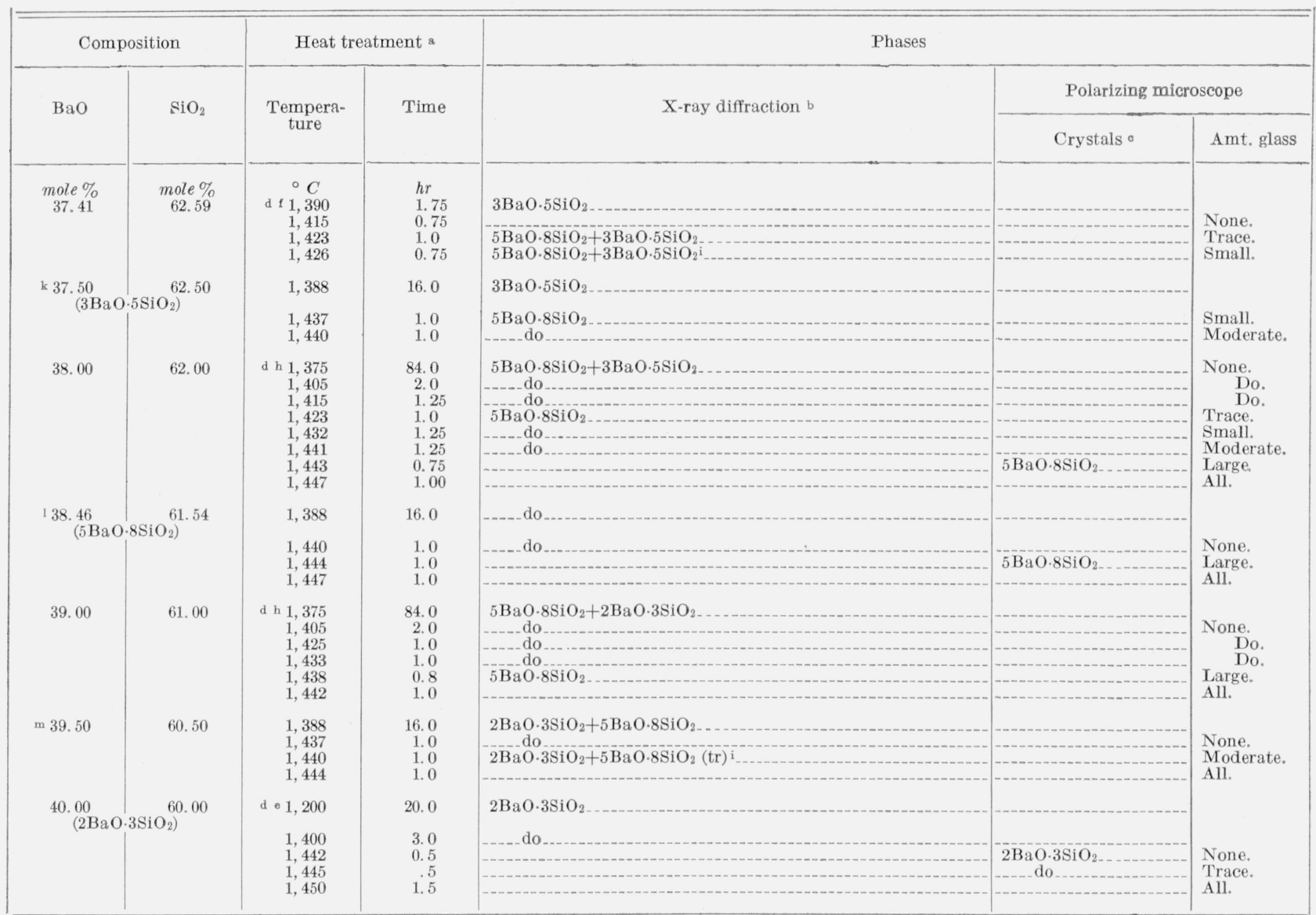

a Except where noted, all specimens were quenched in water, from the temperature indicated.

b Listed in order of relative amounts present, major phase first.

Listed only when no X-ray identification was available.

Starting material; not quenched.

Sample previously heated at $1,460^{\circ} \mathrm{C}$ for $3 / 4 \mathrm{hr}, 1,100^{\circ} \mathrm{C}$ for $17 \mathrm{hr}$, and $1,400^{\circ} \mathrm{C}$

for $1 \mathrm{hr}$. $1 \mathrm{hr}$.

$\mathrm{g}$ Prepared by mixing the appropriate amounts of the compositions low-BaO. $2 \mathrm{SiO}_{2}$ and $34.00 \mathrm{BaO}: 66.00 \mathrm{SiO}_{2}$. h Sample previously heated at $1,300^{\circ} \mathrm{C}$ for $24 \mathrm{hr}, 1,375^{\circ} \mathrm{C}$ for $3.5 \mathrm{hr}, 1,360^{\circ} \mathrm{C}$ for $15.5 \mathrm{hr}$

Interpreted as non-equilibrium phase at the temperature indicated.

j Prepared by mixing the appropriate amounts of the compositions $34.00 \mathrm{BaO}$ : $66.00 \mathrm{SiO}_{2}$ and $35.00 \mathrm{BaO}: 65.00 \mathrm{SiO}_{2}$.

k Prepared by mixing the appropriate amounts of the compositions $37.00 \mathrm{BaO}$ : 63.00 $\mathrm{SiO}_{2}$ and $38.00 \mathrm{BaO}: 62.00 \mathrm{SiO}_{2}$

1 Prepared by mixing the appropriate amounts of the compositions $38.00 \mathrm{BaO}$ : $62.00 \mathrm{SiO}_{2}$ and $39.00 \mathrm{BaO}: 61.00 \mathrm{SiO}_{2}$.

$\mathrm{m}$ Prepared by mixing the appropriate amounts of the compositions $39.00 \mathrm{BaO}$ : $61.00 \mathrm{SiO}_{2}$ and $2 \mathrm{BaO} \cdot 3 \mathrm{SiO}_{2}$.
The present diagram (fig. 1b) differs from Eskola's in several important respects. It shows no solid solution. Instead, 2 discrete compounds occur: $5 \mathrm{BaO} \cdot 8 \mathrm{SiO}_{2}$, melting congruently at $1,446^{\circ} \mathrm{C}$; and $3 \mathrm{BaO} \cdot 5 \mathrm{SiO}_{2}$, melting incongruently at approximately $1,423^{\circ} \mathrm{C}$ to form liquid and $5 \mathrm{BaO} \cdot 8 \mathrm{SiO}_{2}$. In addition, 2 eutectics are located at approximately 34mole-percent $\mathrm{BaO}$ and $1,410^{\circ} \mathrm{C}$ and about 39 -mole percent $\mathrm{BaO}$ and $1,437^{\circ} \mathrm{C}$.

The exact location of the first eutectic relative to the 34-mole-percent $\mathrm{BaO}$ composition could not be established because nonequilibrium conditions prevailed for this composition. Specimens quenched from a comparatively large temperature range of about $10^{\circ}$ contained 2 crystalline phases and glass. However, the 34- and 35-mole-percent $\mathrm{BaO}$ compositions definitely began melting at about $1,410^{\circ} \mathrm{C}$, $10^{\circ}$ below the melting point of $\mathrm{BaO} \cdot 2 \mathrm{SiO}_{2}$, proving the existence of a eutectic in this region.
All compositions between 33.33-mole-percent $\mathrm{BaO}$ and 37.5-mole-percent $\mathrm{BaO}$, when heated below the solidus, contained barium disilicate plus a second phase. The $d$ values of barium disilicate remained essentially constant, indicating the absence of solid solution. A single phase was found to occur at the composition containing 37.5-mole-percent $\mathrm{BaO}$, corresponding to the compound $3 \mathrm{BaO} \cdot 5 \mathrm{SiO}_{2}$. The $\mathrm{X}$-ray diffraction powder pattern for this compound is given in table 4 .

That the compound $3 \mathrm{BaO} \cdot 5 \mathrm{SiO}_{2}$ melts incongruently was ascertained by the observation that this phase does not occur in specimens heated above about $1,423^{\circ} \mathrm{C}$. Above this temperature, for the composition range 37 - to 38-mole-percent $\mathrm{BaO}$, a new phase was detected in equilibrium with glass.

Below the solidus, for the composition 38-molepercent $\mathrm{BaO}$, the new phase occurs with $3 \mathrm{BaO} \cdot 5 \mathrm{SiO}_{2}$. whereas the specimen containing 39-mole-percent 
TABLE 2. X-ray diffraction data for the high temperature form of $\mathrm{BaO} \cdot 2 \mathrm{SiO}_{2} \quad\left(\mathrm{CuK}_{\alpha_{1}}\right.$ radiation)

\begin{tabular}{|c|c|c|c|}
\hline \multicolumn{2}{|c|}{ Levin and Ugrinic } & \multicolumn{2}{|c|}{ Roth and Levin } \\
\hline$d^{\mathrm{a}}$ & $I$ & $d$ & $I / I_{0} \mathrm{~b}$ \\
\hline $\begin{array}{c}A \\
7.00 \\
6.87 \\
5.63 \\
4.75 \\
4.15\end{array}$ & $\begin{array}{r}\% \\
14 \\
13 \\
17 \\
12 \\
8\end{array}$ & $\begin{array}{c}A \\
\quad 6.763 \\
5.514 \\
4.696 \\
4.118\end{array}$ & $\begin{array}{l}\% \\
39 \\
21 \\
23 \\
17\end{array}$ \\
\hline $\begin{array}{l}\text { 4. } 02 \\
\text { 3. } 57 \\
\text { 3. } 39 \\
\text { 3. } 36 \\
\text { 3. } 27\end{array}$ & $\begin{array}{l}77 \\
52 \\
14 \\
23 \\
25\end{array}$ & $\begin{aligned} \text { 3. } 981 \\
3.539 \\
3.331 \mathrm{~B} \\
3.250\end{aligned}$ & $\begin{array}{l}93 \\
74 \\
26 \\
31\end{array}$ \\
\hline $\begin{array}{l}3.15 \\
3.11 \\
2.86 \\
2.76\end{array}$ & $\begin{array}{r}100 \\
87 \\
27 \\
40\end{array}$ & $\begin{array}{l}\text { 3. } 160 \\
\text { 3. } 129 \\
3.095 \\
2.843 \\
2.749\end{array}$ & $\begin{array}{r}46 \\
100 \\
71 \\
21 \\
49\end{array}$ \\
\hline $\begin{array}{l}2.69 \\
2.61 \\
2.36 \\
2.35 \\
2.26\end{array}$ & $\begin{array}{r}7 \\
12 \\
16 \\
16 \\
32\end{array}$ & $\begin{array}{l}\text { 2. } 667 \\
\text { 2. } 593 \\
\text { 2. } 349 \\
\text { 2. } 329 \\
\text { 2. } 245\end{array}$ & $\begin{array}{r}7 \\
11 \\
7 \\
14 \\
33\end{array}$ \\
\hline 2. 23 & 29 & 2. 220 & 17 \\
\hline 2. 21 & 51 & $\begin{array}{l}\text { 2. } 204 \\
2.198\end{array}$ & $\begin{array}{l}37 \\
46\end{array}$ \\
\hline $\begin{array}{l}\text { 2. } 16 \\
\text { 2. } 06 \\
\text { 2. } 05\end{array}$ & $\begin{array}{l}25 \\
21 \\
32\end{array}$ & $\begin{array}{l}\text { 2. } 155 \\
\text { 2. } 059 \\
\text { 2. } 040\end{array}$ & $\begin{array}{l}40 \\
31 \\
19 \\
29\end{array}$ \\
\hline 2.00 & 7 & 1. 992 & 7 \\
\hline 1. 923 & 12 & $\left\{\begin{array}{l}1.916 \\
1.911\end{array}\right.$ & $\begin{array}{r}34 \\
31 \\
9\end{array}$ \\
\hline 1.877 & 17 & $\left\{\begin{array}{l}1.860 \\
1.870 \\
1.862\end{array}\right.$ & $\begin{array}{r}9 \\
11 \\
11\end{array}$ \\
\hline $\begin{array}{l}1.827 \\
1.783 \\
1.732 \\
1.706\end{array}$ & $\begin{array}{r}8 \\
16 \\
9 \\
31 \\
\end{array}$ & $\begin{array}{l}1.824 \\
1.778 \\
1.727 \\
1.703 \\
1.669\end{array}$ & $\begin{array}{r}14 \\
21 \\
7 \\
21 \\
7\end{array}$ \\
\hline $\begin{array}{l}1.601 \\
1.584 \\
1.571\end{array}$ & $\begin{array}{r}13 \\
9 \\
15\end{array}$ & $\begin{array}{l}1.640 \\
1.597 \\
1.582 \\
1.570 \\
1.560\end{array}$ & $\begin{array}{r}7 \\
11 \\
9 \\
11 \\
13\end{array}$ \\
\hline $\begin{array}{l}1.481 \\
1.458 \\
1.408 \\
1.392\end{array}$ & $\begin{array}{r}8 \\
11 \\
6 \\
6\end{array}$ & $\begin{array}{l}1.502 \\
1.477 \\
1.456 \\
1.405 \\
1.387\end{array}$ & $\begin{array}{r}7 \\
7 \\
11 \\
4 \\
6\end{array}$ \\
\hline 1. 378 & \begin{tabular}{c}
9 \\
\hdashline-- \\
-
\end{tabular} & $\begin{array}{l}\text { 1. } 375 \\
\text { 1. } 362 \\
1.328 \\
1.306\end{array}$ & $\begin{array}{r}6 \\
10 \\
6 \\
6\end{array}$ \\
\hline 1.292 & 16 & $\begin{array}{l}\text { 1. } .2900 \\
1.290\end{array}$ & $\begin{array}{l}0 \\
9\end{array}$ \\
\hline $\begin{array}{l}\text { 1. } 288 \\
\text { 1. } 285 \\
\text { 1. } 281\end{array}$ & $\begin{array}{l}16 \\
10 \\
10\end{array}$ & 1. 286 & $\begin{array}{r}13 \\
99\end{array}$ \\
\hline
\end{tabular}

a The $d$ values for this pattern are consistently larger than those found in the present work. As the two patterns were made from the same specimen, it seems likely that the X-ray diffraction equipment used for the older work was out of alinement.

$\mathrm{b}$ The intensities listed are given relative to the strongest peak.

$\mathrm{BaO}$ contains the new phase and $2 \mathrm{BaO} \cdot 3 \mathrm{SiO}_{2}$. Therefore the composition of the new compound occurs between 38- and 39-mole-percent $\mathrm{BaO}$, most probably $5 \mathrm{BaO} \cdot 8 \mathrm{SiO}_{2}$ (containing 38.46 -mole-percent $\mathrm{BaO})$. No change in the X-ray diffraction powder pattern (table 5) was observed up to the liquidus of $5 \mathrm{BaO} \cdot 8 \mathrm{SiO}_{2}\left(1,446^{\circ} \mathrm{C}\right)$. The congruent melting point of the $5: 8$ compound is supported by the unequivocal existence of the eutectic at about 39-
TABLE 3. X-ray diffraction powder pattern for the compound $2 \mathrm{BaO} \cdot 3 \mathrm{SiO}_{2}$

Indexed up to $d \sim 2.1$ (CuKa1 radiation)

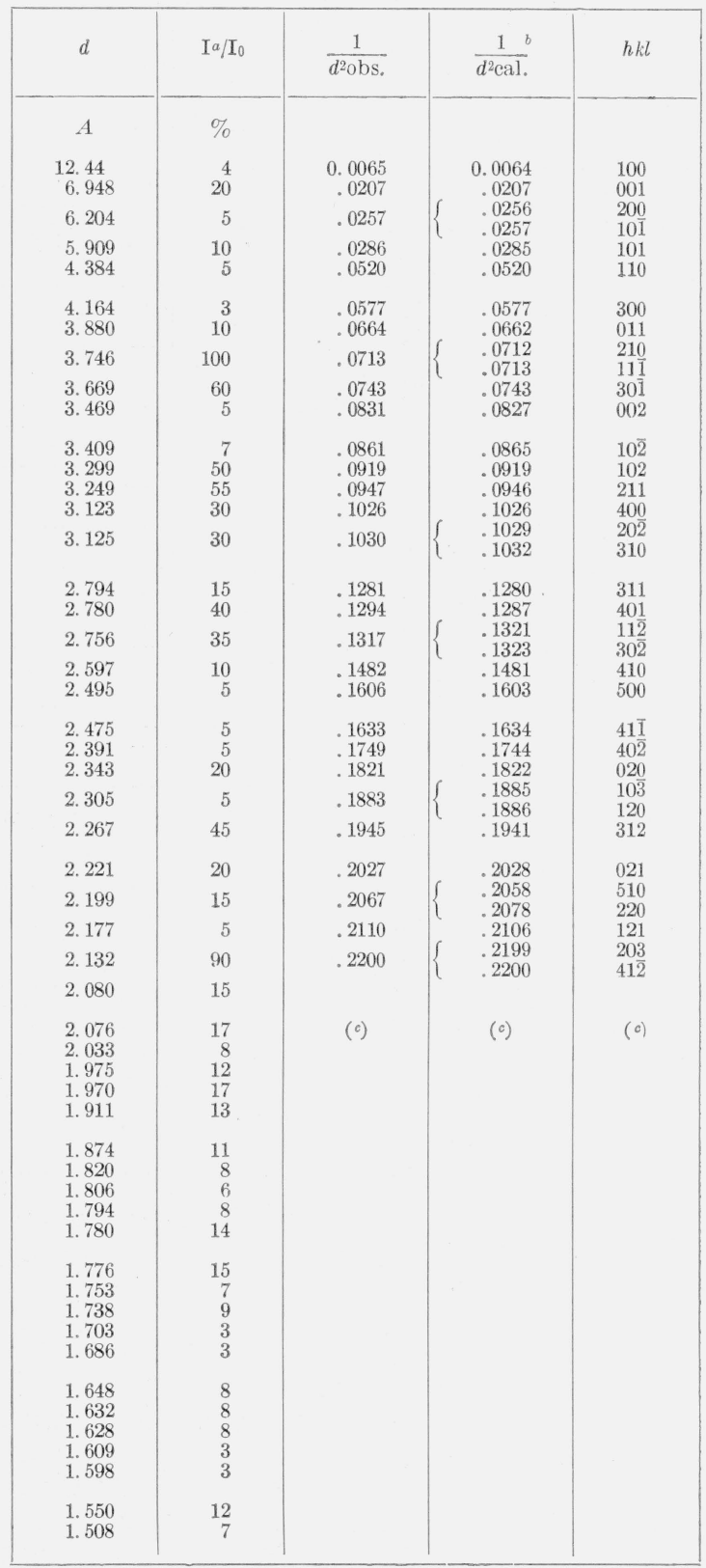

a $\mathrm{I} / \mathrm{I}_{0}$ represents the relative intensity of the diffraction peak relative to the trongest peak.

$b$ These values were calculated on the basis of a unit cell size of $\alpha=12.51 \mathrm{~A}$, $b=4.69 \mathrm{~A}, c=6.97 \mathrm{~A}, \beta=93^{\circ} 23^{\prime}$

No attempt was made to index the rest of the pattern due to the large cell size and low symmetry of the material.

a

mole-percent $\mathrm{BaO}$ (see compositions containing 39- and 39.5-mole-percent $\mathrm{BaO}$ in table 1 ).

Figure 3 shows a schematic comparison of the X-ray diffraction powder patterns of $2 \mathrm{BaO} \cdot 3 \mathrm{SiO}_{2}$, $5 \mathrm{BaO} \cdot 8 \mathrm{SiO}_{2}$, and $3 \mathrm{BaO} \cdot 5 \mathrm{SiO}_{2}$. One notable feature should be mentioned. With decreasing $\mathrm{BaO}$ content, from $2 \mathrm{BaO} \cdot 3 \mathrm{SiO}_{2}$ to $3 \mathrm{BaO} \cdot 5 \mathrm{SiO}_{2}$, the doublet in 
TABLE 4.-X-ray diffraction powder data for the compound $3 \mathrm{BaO} .5 \mathrm{SiO}_{2}$

(CuK $\alpha_{1}$ radiation)

\begin{tabular}{|c|c|c|c|}
\hline$d$ & $I / I_{0^{a}}$ & $d$ & $I / I_{0^{a}}$ \\
\hline$A$ & $\%$ & $A$ & $\%$ \\
\hline 6. 79 & 23 & 2. 039 & 6 \\
\hline 6. 09 & 15 & 2. 024 & 9 \\
\hline 5.17 & 6 & 1. 999 & 23 \\
\hline 4. 253 & 13 & 1. 908 & 20 \\
\hline 3. 983 & 6 & 1.888 & 5 \\
\hline 3. 847 & 100 & 1. 876 & 6 \\
\hline 3. 778 & 81 & 1. 842 & 21 \\
\hline 3. 723 & 19 & 1.817 & 35 \\
\hline 3. 424 & 10 & 1. 800 & 14 \\
\hline 3. 329 & 13 & 1. 786 & 13 \\
\hline 3. 250 & 81 & 1. 764 & 11 \\
\hline 3. 197 & 53 & 1. 729 & 10 \\
\hline 3. 100 & 23 & 1. 702 & 5 \\
\hline 2. 910 & 6 & 1. 627 & 10 \\
\hline 2.875 & 15 & 1.617 & 9 \\
\hline 2. 788 & 56 & 1. 612 & 9 \\
\hline 2. 769 & 28 & 1. 556 & 9 \\
\hline 2. 428 & 5 & 1. 551 & 10 \\
\hline 2. 366 & 9 & 1. 527 & 6 \\
\hline 2. 354 & 28 & 1. 474 & 5 \\
\hline 2. 268 & 34 & 1. 459 & 5 \\
\hline 2. 230 & 19 & 1. 440 & 9 \\
\hline $\begin{array}{l}\text { 2. } 211 \\
\text { 2. } 173\end{array}$ & $\begin{array}{r}38 \\
9\end{array}$ & $\begin{array}{l}\text { 1. } 414 \\
1.394\end{array}$ & $\begin{array}{l}6 \\
6\end{array}$ \\
\hline 2. 156 & 10 & 1. 367 & 5 \\
\hline 2. 120 & 6 & 1. 340 & 11 \\
\hline 2. 068 & 15 & & \\
\hline
\end{tabular}

a The intensity of these peaks is given relative to the height of the strongest peak.

$2 \mathrm{BaO} \cdot 3 \mathrm{SiO}_{2}$, occurring at about $2 \theta=23.5^{\circ}$ and $24^{\circ}$ is shifted to a lower angle while the doublet at $2 \theta=27^{\circ}$ and $28.5^{\circ}$ is shifted to a higher value. This shift is discontinuous. Instead of a continuous shift in $d$ values, as expected for solid solution, 2 phases of unvarying $d$ values were always found for intermediate compositions. Therefore, it must be concluded that there is no appreciable solid solution in the $\mathrm{BaO} \cdot 2 \mathrm{SiO}_{2}-2 \mathrm{BaO} \cdot 3 \mathrm{SiO}_{2}$ system.

\subsection{Criticism of the Solid Solution Diagram}

The reason for the differences between the present diagram and the continuous solid solution interpretation may be found in reviewing the method used and data obtained by Eskola [1].
TABLE 5. X-ray diffraction powder data for the compound $5 \mathrm{BaO} \cdot 8 \mathrm{SiO}_{2}$.

(CuK $\alpha_{1}$ radiation)

\begin{tabular}{|c|c|c|c|}
\hline$d$ & $I / I_{\mathrm{o}}{ }^{\mathrm{a}}$ & $d$ & $I / I_{\mathrm{O}}{ }^{\mathrm{a}}$ \\
\hline $\begin{array}{l}\text { A } \\
6.85 \\
5.99 \\
4.287 \\
3.795 \\
3.735\end{array}$ & $\begin{array}{l}\% \\
11 \\
13 \\
31 \\
78 \\
89\end{array}$ & $\begin{array}{c}\text { A } \\
2.195 \\
2.173 \\
2.141 \\
2.071 \\
1.984\end{array}$ & $\begin{array}{l}\% \\
18 \\
31 \\
13 \\
18 \\
22\end{array}$ \\
\hline $\begin{array}{l}3.264 \\
3.209 \\
3.099 \\
2.852 \\
2.820\end{array}$ & $\begin{array}{r}100 \\
56 \\
38 \\
11 \\
22\end{array}$ & $\begin{array}{l}1.906 \\
1.870 \\
1.823 \\
1.796 \\
1.755\end{array}$ & $\begin{array}{r}18 \\
7 \\
18 \\
31 \\
13\end{array}$ \\
\hline $\begin{array}{l}2.778 \\
2.761 \\
2.345 \\
2.265 \\
2.224\end{array}$ & $\begin{array}{l}78 \\
40 \\
18 \\
27 \\
27\end{array}$ & $\begin{array}{l}\text { 1. } 732 \\
\text { 1. } 635 \\
\text { 1. } 623 \\
\text { 1. } 614 \\
1.551\end{array}$ & $\begin{array}{r}11 \\
18 \\
9 \\
16 \\
13\end{array}$ \\
\hline
\end{tabular}
peak

Table 6 compares the melting point data reported by Eskola with those found in the present investigation. It may be seen that the liquidus values given by Eskola for the 3 intermediate compositions are $3.5^{\circ}$ to $4.5^{\circ}$ higher than the interpolated values obtained from figure 1(b), for the corresponding compositions. If only these compositions had been studied in the present investigation, essential agreement would have been obtained for the liquidus curve. However, an investigation of additional compositions revealed the existence of 2 eutectics, thus eliminating the possibility of complete solid solution. As solidus values obtained by the quenching technique in glass-forming systems are less accurate than liquidus values, especially for compositions remote from the eutectic, a difference of as much as $20^{\circ}$ (table 6 ) is quite possible.

In table 7 the indices of refraction of the discrete phases found in the present study are compared with the values given by Eskola for 6 compositions. As in the case of the melting point data, if only these compositions are considered, solid solution would be indicated. However, the indices of refraction obtained by Eskola are compatible with the indices found for the discrete phases, identified in the present

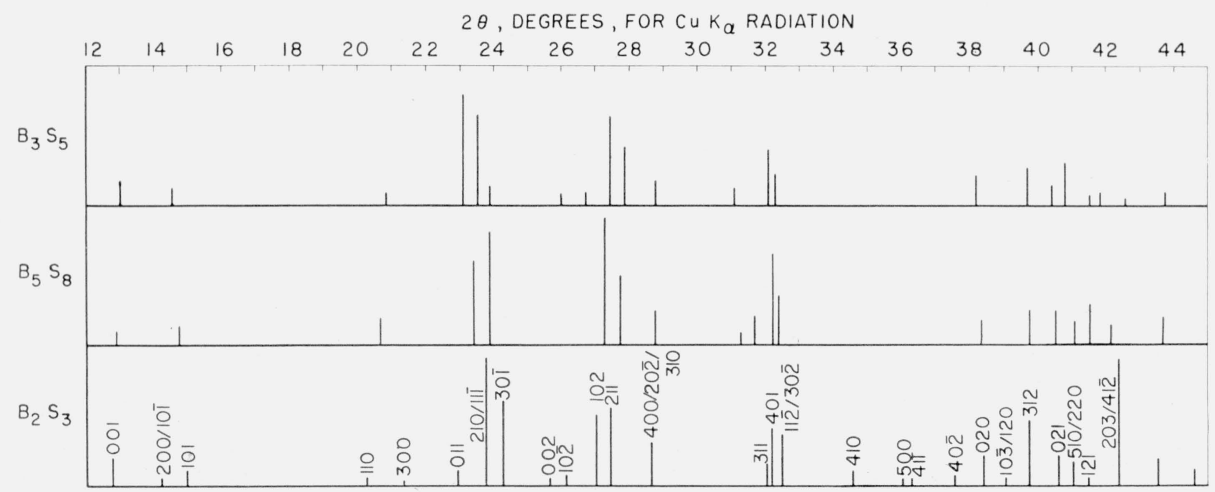

Figure 3. Schematic X-ray diffraction powder patterns for the compounds $3 \mathrm{BaO} \cdot 5 \mathrm{SiO}_{2}$, $5 \mathrm{BaO} \cdot 8 \mathrm{SiO}_{2}$, and $2 \mathrm{BaO} \cdot 3 \mathrm{SiO}_{2}$. 
work by X-ray methods. The interpretation of the indices for the specimen containing 35.11-mole-percent $\mathrm{BaO}$, for example, is that the extreme indices reported by Eskola are the $\alpha$ for $\mathrm{BaO} \cdot 2 \mathrm{SiO}_{2}$ and the $\gamma$ for $3 \mathrm{BaO} \cdot 5 \mathrm{SiO}_{2}$.

In postulating solid solution, Eskola placed great reliance on the observation that for the mixture containing 37-mole-percent of $\mathrm{BaO}$, crystals formed at temperatures below the solidus possessed lower indices than crystals formed above the solidus. However, the present diagram, in which the compound $3 \mathrm{BaO} \cdot 5 \mathrm{SiO}_{2}$ is shown to melt incongruently to $5 \mathrm{BaO} \cdot 8 \mathrm{SiO}_{2}$ and liquid, is equally consistent with this observation.

Concerning the polymorphism of $\mathrm{BaO} \cdot 2 \mathrm{SiO}_{2}$, the corresponding indices of refraction of the high and low forms are the same within the limits of accuracy of the immersion method $( \pm 0.003)$. Thus the 2 forms are optically indistinguishable.

The conclusion that little or no solid solution exists in the binary system $\mathrm{BaO}_{-} \mathrm{SiO}_{2}$, is in agreement with the opinions of Douglass [7], based on the structure of sanbornite. However, considerable solid solution has been postulated in $\mathrm{BaO} \cdot 2 \mathrm{SiO}_{2}$ with $\mathrm{Al}_{2} \mathrm{O}_{3}$ by Thomas [4] and with $\mathrm{B}_{2} \mathrm{O}_{3}$ by Levin and Ugrinic [5]. Such systems might be reviewed with the idea of detecting the presence of the $3: 5$ and 5:8 compounds within the ternary system. It seems likely that a further study of these, or other ternary systems involving $\mathrm{BaO}$ and $\mathrm{SiO}_{2}$, would reveal that little solid solution occurs between any of the 4 compounds discussed here, involving a change in the ratio of the large cation to the tetrahedrally coordinated cation.

TABLE 6. Comparison of melting point data for compositions in the system $\mathrm{BaO} \cdot 2 \mathrm{SiO}_{2}-2 \mathrm{BaO} \cdot 3 \mathrm{SiO}_{2}$

\begin{tabular}{|c|c|c|c|c|c|}
\hline \multicolumn{2}{|c|}{ Composition } & \multicolumn{2}{|c|}{ Liquidus } & \multicolumn{2}{|c|}{ Solidus } \\
\hline $\mathrm{BaO}$ & $\mathrm{SiO}_{2}$ & Eskola [1] & $\begin{array}{l}\text { Roth \& } \\
\text { Levin a }\end{array}$ & Eskola [1] & $\begin{array}{l}\text { Roth \& } \\
\text { Levin a }\end{array}$ \\
\hline $\begin{array}{c}\text { mole \% } \\
33.33 \\
35.11 \\
37.02 \\
38.25 \\
40.00\end{array}$ & $\begin{array}{c}\text { mole \% } \\
66.67 \\
64.89 \\
62.98 \\
61.75 \\
60.00\end{array}$ & $\begin{array}{c}{ }^{\circ} C \\
\quad 1,420 \\
\text { b } 1,433.5 \\
\text { b } 1,445.5 \\
\text { b } 1,449.5 \\
\text { b } 1,449.5\end{array}$ & $\begin{array}{l}\circ C \\
1,420 \\
1,429 \\
1,442 \\
1,445 \\
1,447\end{array}$ & $\begin{array}{l}{ }^{\circ} C \\
\text { b } 1,421 \\
\text { b } 1,433 \\
\text { b } 1,439\end{array}$ & $\begin{array}{l}{ }^{\circ} C \\
1,410 \\
1,410 \\
1,423\end{array}$ \\
\hline
\end{tabular}

a Obtained from figure 1(b), to correspond to the listed compositions, which were studied by Eskola.

b Interpolated from data in table 2 of reference [1].

\section{Summary}

The phase equilibrium diagram for the subsystem $\mathrm{BaO} \cdot 2 \mathrm{SiO}_{2}-2 \mathrm{BaO} \cdot 3 \mathrm{SiO}_{2}$ within the binary system $\mathrm{BaO}-\mathrm{SiO}_{2}$ has been revised. Fourteen compositions were studied by the quenching method. Phases were identified by X-ray diffraction powder patterns and with the aid of the polarizing microscope. The subsystem includes 4 binary compounds: the endmembers, $\mathrm{BaO} \cdot 2 \mathrm{SiO}_{2}$ and $2 \mathrm{BaO} \cdot 3 \mathrm{SiO}_{2}$, and 2 new compounds, $3 \mathrm{BaO} \cdot 5 \mathrm{SiO}_{2}$ and $5 \mathrm{BaO} \cdot 8 \mathrm{SiO}_{2}$. No perceptible solid solution was found between any of these compounds, contrary to previously published diagrams, which show complete solid solution between barium disilicate and dibarium trisilicate. Barium disilicate was found to have a quenchable and slowly reversible phase transformation at about $1,350^{\circ} \mathrm{C}$. The mineral sanbornite corresponds to the low temperature form. The compound $5 \mathrm{BaO} \cdot 8 \mathrm{SiO}_{2}$ and the end-member $2 \mathrm{BaO} \cdot 3 \mathrm{SiO}_{2}$ melt congruently at $1,446^{\circ}$ and $1,447^{\circ} \mathrm{C}$, respectively. A eutectic exists between the 2 at about $1,437^{\circ}$ $\mathrm{C}$, and 39-mole-percent $\mathrm{BaO}$. The compound $3 \mathrm{BaO} \cdot 5 \mathrm{SiO}_{2}$ melts incongruently at about $1,423^{\circ}$ $\mathrm{C}$ to form $5 \mathrm{BaO} \cdot 8 \mathrm{SiO}_{2}$ and liquid. A eutectic between $\mathrm{BaO} \cdot 2 \mathrm{SiO}_{2}$ and $3 \mathrm{BaO} \cdot 5 \mathrm{SiO}_{2}$ occurs at about $1,410^{\circ} \mathrm{C}$ and 34-mole-percent $\mathrm{BaO}$. Dibarium trisilicate was found to be monoclinic with $a=12.51$ $\mathrm{A}, b=4.69 \mathrm{~A}, c=6.97 \mathrm{~A}$, and $\beta=93^{\circ} 23^{\prime}$.

\section{References}

[1] P. Eskola, Am. J. Sci. 4, 331 (1922).

[2] N. L. Bowen, J. Wash. Acad. Sci. 8, 265 (1918).

[3] A. F. Rogers, Am. Mineralogist 17, 161 (1932).

[4] R. H. Thomas, J. Am. Ceram. Soc. 33, 35 (1950).

[5] E. M. Levin and G. M. Ugrinic, J. Research NBS 51, 37 (1953) RP2430.

[6] N. A. Toropov, F. Ya. Galakhov, and I. A. Bondar, Bull. Acad. Sci. U.S.S.R., Div. Chem. Sci. 1955, 3 (1955).

[7] R. M. Douglass, Am. Mineralogist 43, 517 (1958).

[8] R. S. Roth and E. M. Levin, Am. Mineralogist 44, No. 3 and 4 (1959).

[9] F. A. Mauer, Bridge-type furnace controller using Brown servoamplifier (informal communication); see also R. H. Bogue, The Chemistry of Portland Cement, 2d ed., p. 311. (Reinhold Publ. Corp., 1955).

[10] A. E. Austin, J. Am. Ceram. Soc. 30, 218 (1947).

[11] F. Ordway, J. Research NBS 48, 152 (1952) RP2299.

TABLE 7. Comparison of optical data for compositions in the system $\mathrm{BaO} \cdot 2 \mathrm{SiO}_{2}-2 \mathrm{BaO} \cdot 3 \mathrm{SiO}_{2}$

(Indices of refraction by Eskola for continuous solid solution series; indices by Roth and Levin for discrete compounds)

\begin{tabular}{|c|c|c|c|c|c|c|c|c|c|c|}
\hline \multicolumn{2}{|c|}{ Composition } & \multirow{2}{*}{ Compound } & \multicolumn{7}{|c|}{ Indices of refraction $\left(\lambda_{D}, 30^{\circ} \mathrm{C}\right)$} & \multirow{2}{*}{$\begin{array}{l}\text { Index of } \\
\text { quenched } \\
\text { glass } \\
\left(30^{\circ}\right)\end{array}$} \\
\hline $\mathrm{BaO}$ & $\mathrm{SiO}_{2}$ & & \multicolumn{3}{|c|}{ Eskola [1] } & \multicolumn{3}{|c|}{ Roth and Levin } & Sign and $2 \mathrm{~V}$ & \\
\hline $\begin{array}{c}\text { Mole \% } \\
33.33\end{array}$ & $\begin{array}{c}\text { Mole \% } \\
\quad 66.67\end{array}$ & $\mathrm{~L}-\mathrm{BaO} \cdot 2 \mathrm{SiO}_{2}$ & & & & 1. 596 & 1.612 & 1.621 & Negative, large. & \\
\hline 35.11 & 64.89 & $\mathrm{H}-\mathrm{BaO} \cdot 2 \mathrm{SiO}_{2}$ & $\begin{array}{l}1.597 \\
1.597\end{array}$ & $\begin{array}{l}1.612 \\
1.612\end{array}$ & $\begin{array}{l}1.621 \\
1.636\end{array}$ & 1.596 & 1.611 & 1.619 & Negative, $70^{\circ} \ldots$ & 1. 608 \\
\hline $\begin{array}{l}37.02 \\
37.50\end{array}$ & $\begin{array}{l}62.98 \\
62.50\end{array}$ & $3 \mathrm{BaO} \cdot 5 \mathrm{SiO}_{2}$ & 1.612 & 1.615 & 1. 638 & 1.612 & 1.616 & 1.636 & Positive, $35^{\circ}$ & 1.625 \\
\hline $\begin{array}{l}38.25 \\
38.46\end{array}$ & $\begin{array}{l}61.75 \\
61.54\end{array}$ & $5 \mathrm{BaO} 8 \mathrm{SiO}_{2}$ & 1.616 & 1.620 & 1. 639 & 1.617 & 1.622 & 1.638 & Positive, $40^{\circ}$ & 1.629 \\
\hline $\begin{array}{l}39.50 \\
40.00\end{array}$ & $\begin{array}{l}60.50 \\
60.00\end{array}$ & $2 \mathrm{BaO} 3 \mathrm{SiO}_{2}$ & $\begin{array}{l}1.619 \\
1.620\end{array}$ & $\begin{array}{l}1.624 \\
1.625\end{array}$ & $\begin{array}{l}1.644 \\
1.645\end{array}$ & 1.618 & 1.623 & 1.643 & Positive, $35^{\circ}$ & 1.635 \\
\hline
\end{tabular}

Washington, January 6, 1959. 